九州大学学術情報リポジトリ

Kyushu University Institutional Repository

Estimation model of water requirement in farmland : Referring to the Thailand gravity irrigation district (1)

Fukuda, Tetsuro

Faculty of Agriculture, Gradute School, Kyushu University

https://doi.org/10.5109/4695

出版情報：九州大学大学院農学研究院紀要. 50 (2)，pp.871-881，2005-10-01. Faculty of Agriculture, Kyushu University

バージョン：

権利関係 : 


\title{
Estimation model of water requirement in farmland - Referring to the Thailand gravity irrigation district (1) -
}

\author{
Tetsuro FUKUDA* \\ Laboratory of Irrigation and Water Utilization, Division of Regional Environment Science, \\ Department of Bioproduction Environmental Sciences, Faculty of Agriculture, \\ Graduate School, Kyushu University, Fukuoka 812-8581, Japan \\ (Received July 12, 2005 and accepted July 26, 2005)
}

\begin{abstract}
With the aim of estimation of an agricultural water demand and establishment of the optimum water allocation technique, the research was undertaken. To begin with, the following were developed referring to the gravity irrigation district in Thailand: Estimation model of a water demand in paddy field and upland field. The data necessary for the model was collected and was analyzed, and evaporation and crop coefficients, etc. were clarified. On the paddy field, the material is insufficient, and it is necessary to clarify by the observation.
\end{abstract}

\section{INTRODUCTION}

In Thailand, a demand such as increase and industrial water of the electric power demand expands with the development of the industry, and the agricultural water is pressed. And, the water level of the dam is unlike our country without recovering, because non-irrigation stage which functions as the time which stores the water in the dam does not exist, very much, while it lowers year by year. From the viewpoint of the effective utilization of such a social conditions and water resources, it is necessary to carry out the efficient utilization of the agricultural water.

This study is a series of research for establishing the technique of estimation of an agricultural water demand and optimum water allocation referring to the gravity irrigation district in Thailand.

The procedure of this a series of work almost as following change will. (1) The estimation of a field level water demand quantity. (2) A grasp of the planting area. (3) The estimation of the diversion requirement for paddy area. (4) The water allocation operation.

In the field, various crops are cultivated as besides the paddy rice field crop. To begin with, it is necessary to estimate water demand of the field level to the every crop. Next, it is necessary to grasp area under cultivation of each crop. For water requirement estimation the area of the crop cultivation most affects. By analyzing the change pattern of the area under cultivation in the past, prediction of a future area under cultivation becomes possible. Even that clarifies the relation with discharge and gate opening and also water level is necessary to allocate the water requirement corresponding to water demand quantity to each area accurately.

\footnotetext{
* Corresponding author (E-mail: tfukuda@bpes.kyushu-u.ac.jp)
} 
Referring to Sam Chuk district.which is the gravity irrigation district in this paper, a water demand estimation model of the field level is constructed. The Sam Chuk district is located for northwest about $50 \mathrm{~km}$ of Bangkok, and it is located in both shores in the span river which flows the west in the Chao Phraya river, and command area is about 50000 hectares.

\section{ESTIMATION OF IRRIGATION WATER REQUIREMENT}

\section{Water balance model and equation}

For deciding irrigation water requirement in upland field, it is supposed that soil moisture changes between moisture holding capacity after 24 hours (or field capacity) and the permanent wilting point. Then, the tank in which the available moisture $(A M)$ is equal to the depth is assumed in the underground, and it is considered that the moisture changes in the capacity of the tank. The outline of the water balance model is shown in Fig. 1.

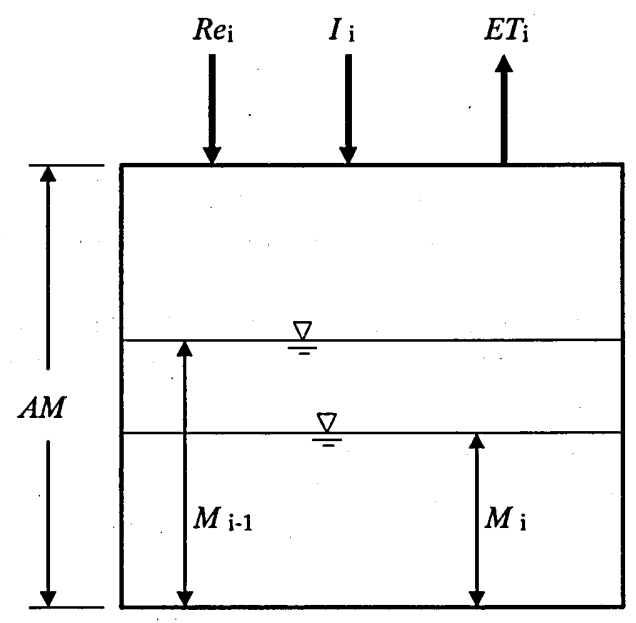

Fig. 1. Water Balanc Model in Upland Field

The water balance equation is as follows:

$$
M_{i}=M_{i-1}+R e_{i}+I_{i}-E T_{i}
$$

Where $M_{\mathrm{i}}$ is soil moisture on the $\mathrm{i}^{\text {th }}$ day, $M_{\mathrm{i}-1}$ is soil moisture on the (i-1) $)^{\text {th }}$ day, $R e_{\mathrm{i}}$ is effective rainfall on the $\mathrm{i}^{\text {th }}$ day, $I_{\mathrm{i}}$ is irrigation water on the $\mathrm{i}^{\text {th }}$ day and $E T_{\mathrm{i}}$ is evapotranspiration on the $\mathrm{i}^{\text {th }}$ day.

\section{Estimation of the factors concerning the water balance}

We can rewrite the water balance equation about irrigation water $I_{\mathrm{i}}$ as follows. 


$$
I_{i} \leq A M-M_{i-1}-R e_{i}+E T_{i}
$$

It is clear from the equation (2) that the following three items are necessary to estimate irrigation water requirement.

- Available soil moisture, in other words ability to be able to hold moisture in the soil.

- Evapotranspiration, in other words consumptive water use for every crop.

- Rainfall data.

\section{Available soil moisture}

Available moisture ( $A M)$ in Fig. 1, which is soil moisture between field capacity (or moisture holding capacity after 24 hours) and the permanent wilting point, is soil moisture which can be effectively utilized by the crop. Generally, the idea of field capacity is adopted as an upper limit of available moisture in arid area in foreign countries. However, there are many cases in which they reach in point of time which passed after large rainfall and a few days on the field capacity in the meaning which makes descent end of gravitational water to be a standard. Recently, field capacity is generally defined as time regulation. Soil moisture, which is held in soil 24 hours after there has been heavy rainfall or adequate irrigation, is adopted as moisture holding capacity after 24 hours. Moisture tension of moisture holding capacity after 24 hours is about $1 / 30-1 / 10$ bars and they become around 1.5-2.0 at $\mathrm{pF}$ value. These values depend on the kind of soil.

On the other hand, a permanent wilting point (around $\mathrm{pF}=4.2$ ) is rarely adopted as a minimum value of available moisture. Recently, the following theory has been taking root. We should adopt soil moisture, which impedes normal growth a little, as a minimum value of soil moisture. Depletion of moisture content is soil moisture, which is not to be able to grow normally. Moisture tension and the $\mathrm{pF}$ value of depletion of moisture content is about 1 bars and around $\mathrm{pF}=3.0$ respectively. Of course these values depend on the kind of soil.

Amount of moisture between field capacity and depletion of moisture content for normal growth is called readily available moisture $(R A M)$ especially.

\section{Effective soil layer}

Effective soil layer is the depth at which soil moisture is consumed by evaporation from the ground surface and absorption of moisture by the roots of crops. Because of differences in root distribution, consumptive use of moisture in an effective soil layer is uniform. Generally it decreases from upper to lower layers.

\section{Soil moisture extraction pattern (SMEP)}

SMEP shows ratio of decrease in quantity for each soil layer compared with the entire effective soil layer. If we divide the root zone into four layers, consumptive use of moisture for each layer is usually $40,30,20,10 \%$ from the upper layer.

\section{Total Readily Available Moisture (TRAM)}

$T R A M$ is adopted as available moisture when making an irrigation plan. TRAM is total moisture to be consumed in an effective soil layer when soil moisture originates from moisture holding capacity after 24 hours to the depletion of moisture content in a 
controlled layer. The controlled layer consumes the most moisture in an effective soil layer.

it lowers from 24 hour water capacity to the growth inhibition moisture point soil layer effective most water consumption many restriction soil layer the total body water consumed in effective soil layer it calls call.

$$
T R A M=\left(F_{c}-M_{L}\right) \cdot D \times 1 / C_{P}(\mathrm{~mm})
$$

Where $F_{\mathrm{C}}$ is moisture holding capacity after 24 hours (capacity \%), $M_{\mathrm{L}}$ is depletion of moisture content (capacity \%), $D$ is thickness of controlled layer (mm) and $C_{\mathrm{P}}$ is value of $S M E P$ in controlled layer (\%).

Table 1 shows moisture tension and available moisture of 4 soil sample which were collected in the Sam Chuk Project.

Table 1. Available Soil Moisture

(Data is from RID report)

\begin{tabular}{crccc}
\hline \multirow{2}{*}{$\begin{array}{c}\text { Location } \\
\text { No. }\end{array}$} & $\begin{array}{c}\text { Depth } \\
(\mathrm{cm})\end{array}$ & \multicolumn{2}{c}{ Moisture Retention } & \multirow{2}{*}{$\begin{array}{c}\text { Available } \\
\text { Moisture }\end{array}$} \\
\cline { 3 - 4 } 1 & $0-30$ & 26.2 & 13.1 & 13.1 \\
& $30-60$ & 25.4 & 12.8 & 12.6 \\
2 & $0-30$ & 26.4 & 13.3 & 13.1 \\
& $30-60$ & 26.8 & 14.4 & 12.4 \\
3 & $0-30$ & 26.2 & 14.9 & 11.3 \\
& $30-60$ & 25.7 & 13.7 & 12.0 \\
4 & $0-30$ & 27.1 & 14.0 & 13.1 \\
& $30-60$ & 25.0 & 14.0 & 11.0 \\
Average & $0-30$ & & & 12.7 \\
& $30-60$ & & & 12.0 \\
\hline
\end{tabular}

In Table 1 , it seems that permanent wilting point is a lower limit of available moisture, and field capacity is upper limit.

Therefore, by replacing depletion of moisture content with the permanent wilting point in the equation (3) in Sam Chuk district, TRAM shall be calculated. And, it is general to use TRAM instead of available moisture $A M$ of the equation (2)

In these results we assume two depths of effective root zones, $30 \mathrm{~cm}$ and $60 \mathrm{~cm}$ respectively. In either case, it assumes that $S M E P$ for each layer is $40,30,20,10 \%$ from the upper layer. Calculated values of TRAM are as follows:

In the case of $30 \mathrm{~cm}$ effective root zone: In the case of $60 \mathrm{~cm}$ effective root zone:
(O) $12.7 \times 75 / 40=23.8 \div 24(\mathrm{~mm})$
$12.7 \times 75 / 30=31.8$
(C) $12.7 \times 150 / 40=47.6 \doteqdot 48(\mathrm{~mm})$
$12.7 \times 75 / 20=47.6$
$12.7 \times 150 / 30=63.5$
$12.7 \times 75 / 10=95.3$
$12.7 \times 150 / 20=90.0$
$12.7 \times 150 / 10=180.0$

Therefore, it is assumed that the effective root zone of upland crops and vegetables is 
$30 \mathrm{~cm}$, and it is possible to estimate TRAM to $24 \mathrm{~mm}$. It is assumed that the effective root zone of sugarcane is $60 \mathrm{~cm}$, and it is possible to estimate $T R A M$ to $48 \mathrm{~mm}$.

\section{Estimation of consumptive water use (evapotranspiration)}

Penman, E-pan and Blaney Criddle Methods, etc are the method used to calculate consumptive water use from meteorological data.

In E-pan method, it calculates evapotranspiration by evaporimeter evaporation.

In Blaney Criddle method, it calculates evapotranspiration from mean temperature and sunshine duration.

Penman Method uses mean temperature, relative humidity, wind velocity and sunshine duration. It is easy to obtain these meteorological data. Penman's equation is very complicated, though this method is generally very reliable because computers can now be used.

Consumptive water use is obtained by multiplying the crop coefficient to potential evaporation by penman method.

The calculation of potential evaporation by Penman method

Penman's equation is as follows:

$$
E T_{0}=\frac{\Delta}{\Delta+\gamma} \cdot \frac{S}{\ell}+\frac{r}{\Delta+\gamma} f\left(u_{2}\right)\left(e_{a}-e_{d}\right)
$$

Where $S$ is Net ray $\left(\mathrm{MJ} \cdot \mathrm{m}^{-2}\right), \ell$ is water evaporation heat $\left(\mathrm{MJ} \cdot \mathrm{kg}^{-1}\right), \Delta$ is slope of saturated vaper pressure curve at $t$ temperature $\left(\mathrm{mb} \cdot{ }^{\circ} \mathrm{C}^{-1}\right), \gamma$ is psychrometer constant $\left(0.66 \mathrm{mb} \cdot{ }^{\circ} \mathrm{C}^{-1}\right), f\left(u_{2}\right)$ is wind velocity function, $e_{\mathrm{a}}$ is saturated vaper pressure $(\mathrm{mb})$ and $e_{\mathrm{d}}$ is real vaper pressure $(\mathrm{mb})$.

Comparison of mean monthly evapotranspiration between Penman's method ( $E$ pen) and Epan method (Epan) is shown in Fig. 2. Fig. 2 shows that Epen is nearly equal to

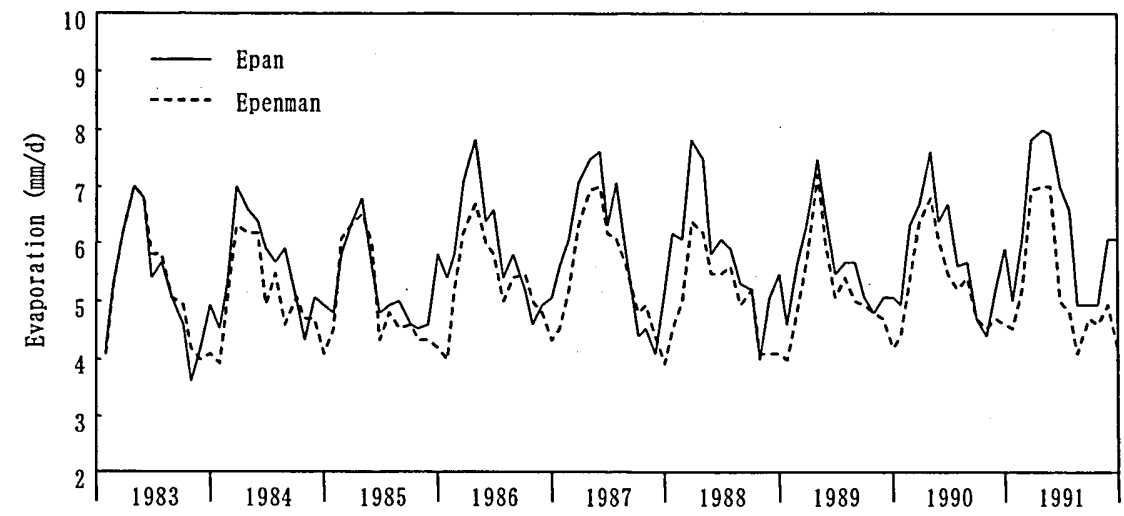

Fig. 2. Relation between pan evaporation and potential evaporation by Penman method 


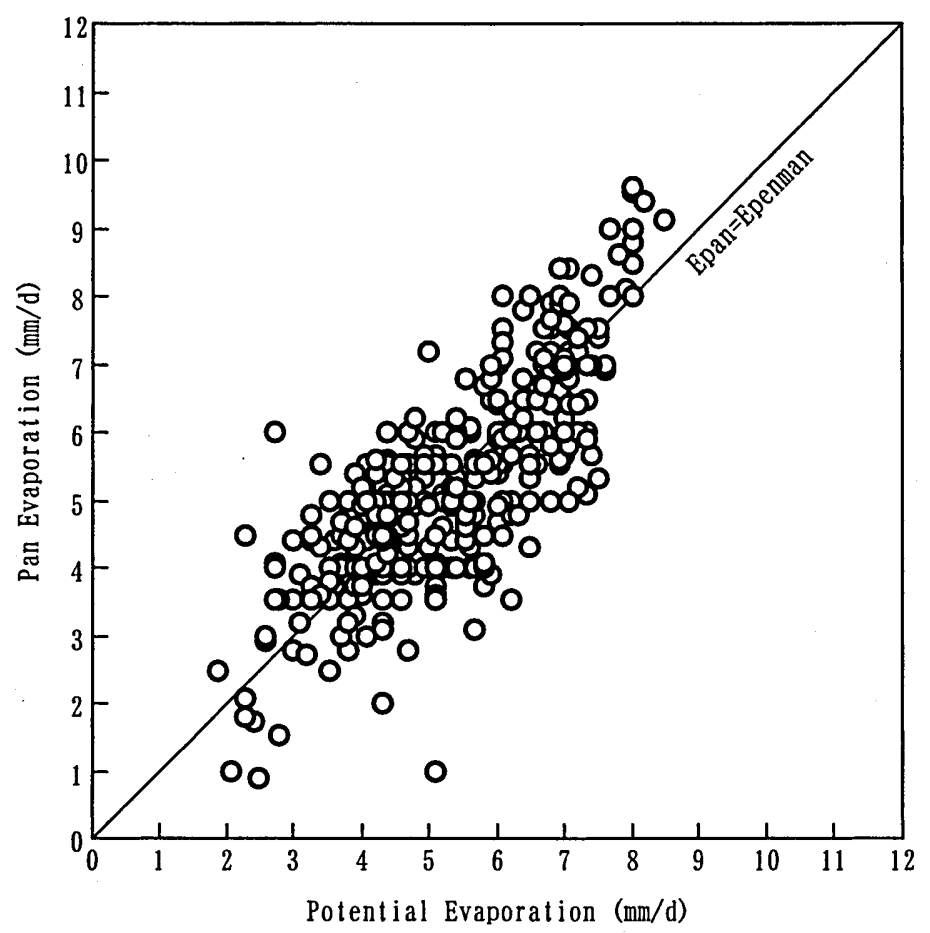

Fig. 3. Relation between pan evaporation and potential evaporation by Penman method (1983)

Epan. Mean monthly evaporation by Penman's method is estimated from daily meteorological data.

Fig. 3 shows a comparison between $E$ pen and $E$ pan in 1983. If we use a regression equation, we can derive $E$ pan $=a \cdot E$ pen.

Correlation coefficient $\gamma$ is 0.786 , and coefficient $a$ of the linear regression equation is 1.0. In other year (1984 1991), coefficient $a$ ranges between 1.037 and 1.167, so we can suppose $E$ pan $\doteqdot E$ pen. Therefore, we can use the Pan Coefficient $(K \mathrm{p})$ as a crop coefficient.

Fig. 4 shows monthly variation of potential evaporation by Penman's equation for 1983-1991. Table 2 shows monthly mean value of the potential evaporation for abovementioned 9 years.

In Fig. 4, it is shown that the dispersion of potential evaporation by the year is small, the range of variation is about mean value $\pm 1 \mathrm{~mm}$ in either month.

Therefore, we can use the value in Table 2 as monthly mean evaporation. The evaporation is the most fundamental element in estimation of water requirement. We can estimate monthly evaporation as the value which does not depend on the year. That is very significant in the water management planning. 


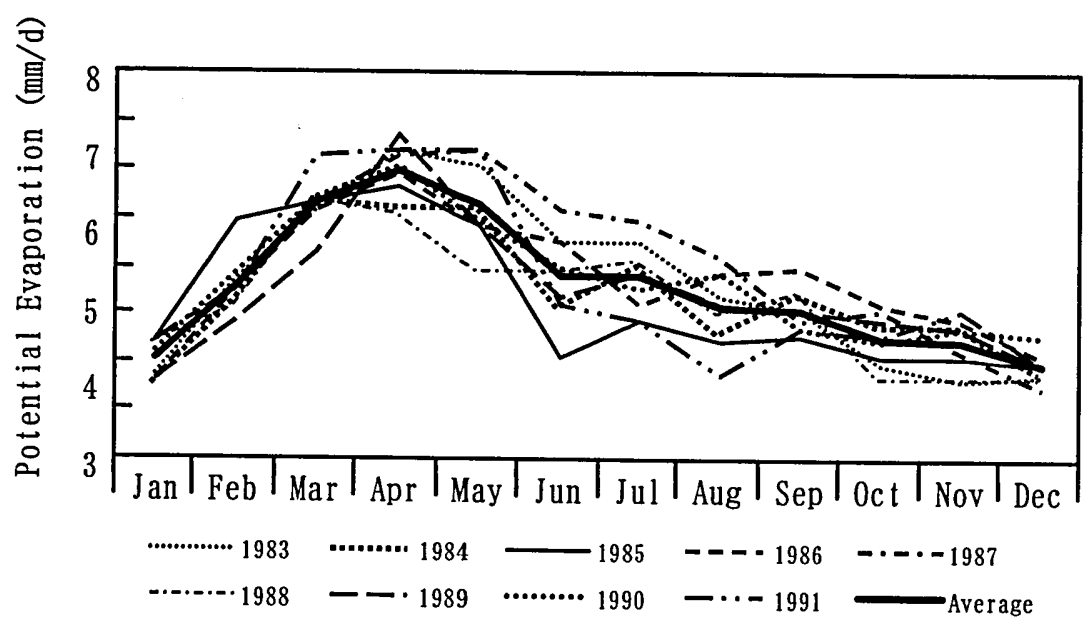

Fig. 4. Change in mean monthly potential evaporation

Table 2. Potential Evaporation calculated by Penman Method

\begin{tabular}{ccccccccccccc}
\hline Month & 1 & 2 & 3 & 4 & 5 & 6 & 7 & 8 & 9 & 10 & 11 & 12 \\
\hline Epen & 4.3 & 5.3 & 6.4 & 6.8 & 6.4 & 5.4 & 5.4 & 5.0 & 5.0 & 4.6 & 4.6 & 4.3 \\
\hline
\end{tabular}

\section{Crop coefficient}

For crop coefficient $(K c)$ which is the ratio of measured evapotranspiration for each crop by lysimeter to evapotranspiration by Penman's method. It is possible to estimate consumptive water use for each crop using the following estimation (5).

$$
E T=K c \cdot E T_{0}
$$

The crop coefficient is different from in each growing stage. However, in the case that planting time is different from plot to plot as in this area, in this case, crop coefficient should be applied average crop coefficient through planted season. The crop coefficient average of main crops is shown in Table 3.

The kinds of crops are not clear, so it is convenient classify.

- upland crops or vegetables

Table 3. Pan Coefficient $(K \mathrm{p})$

\begin{tabular}{ccccccccccc}
\hline Maize & Sorghum & Soybean & Groundnut & Mungbean & Sesame & Tobacco & Cotton & Cauliflower & Kale & Sugarcane \\
\hline 0.87 & 0.82 & 0.88 & 0.81 & 0.7 & 0.78 & 0.99 & 0.69 & 0.87 & 0.61 & 0.9 \\
\hline
\end{tabular}


- sugarcane

- orchard or perennial plant

If the crop coefficient of upland crops and vegetables is supposed to be the average crop coefficient in Table 3 except for sugarcane, $K \mathrm{p}$ is 0.80 and the $K \mathrm{p}$ of sugarcane is 0.90 . $K \mathrm{p}$ of orchards and perennial plants is 1.0 .

\section{Irrigation water estimation method}

Intermittent irrigation and frequent irrigation with little water

There are two method of irrigation. We irrigate in accordance with the amount of available moisture immediately, and we will not irrigate till soil moisture reaches depletion of moisture content. This method is called intermittent irrigation. The other one is called frequent irrigation with little water. Soil moisture is always maintained in a half dry condition or less than depletion of moisture content, and we irrigate frequently with little water. It is possible to use rainfall most effectively in areas where there are insufficient water resources, this method is usually adopted.

\section{Simulation method}

In the case of calculation of irrigation water from equation (2), if the irrigation method and effective rainfall are not clear, irrigation water requirement cannot be decided. I will explain the estimation method of irrigation water assuming daily irrigation.

\section{The effective rainfall $\left(\mathrm{Re}_{i}\right)$}

Effective rainfall should be considered experiencing $20 \%$ loss. So effective rainfall is $80 \%$ of rainfall in a day $\left(R_{\mathrm{i}}\right)$.

In the case of substitution of this theory for equation (1), soil moisture $\left(M_{\mathrm{i}}\right)$ should be $M_{\mathrm{i}} \leqq A M(=T R A M)$.

Maximum value of effective rainfall $\left(R e_{\max }\right)$ is as follows.

$$
R e_{\max }=T R A M-M_{i}+E T_{i}
$$

Therefore effective rainfall $\left(R e_{\mathrm{i}}\right)$ is as follows.

$$
R e_{i}=\min \left(R e_{i} * 0.8, R e_{\max }\right)
$$

Where $\min \left(x_{1}, x_{2}\right)$ means that we have to get a lower value within each item.

\section{Irrigation water $\left(I_{i}\right)$}

In the case of equation (1), irrigation water is the minimum amount of irrigation water $\left(I_{i}\right)$ that satisfies the following equation.

$$
\text { soil moisture } M_{\mathrm{i}} \geqq 0
$$

Eventually, it should be decided when irrigation water requirement $\left(I_{i}\right)$ should not exceed consumptive water use $\left(E T_{\mathrm{i}}\right)$.

$$
I_{i}=\min \left(E T_{i}-M_{i-1}-R e_{i}, 0\right)
$$




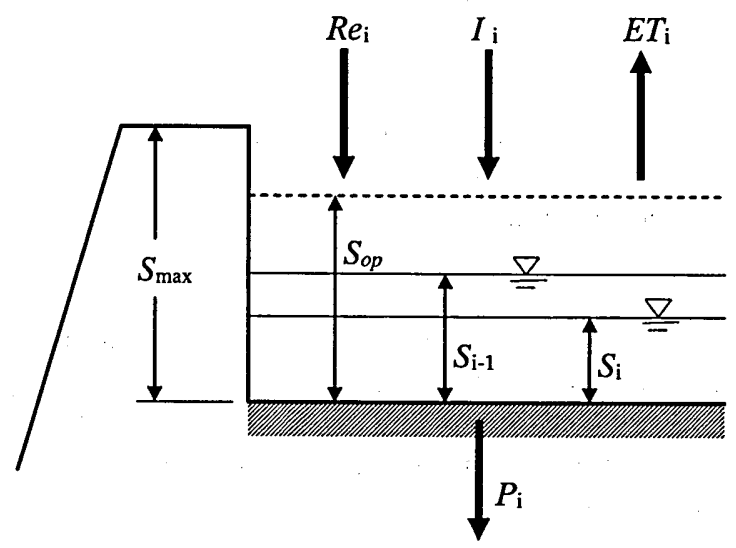

Fig. 5. Water Balanc Model in Paddy Field

Where $\max \left(x_{1}, x_{2}\right)$ means that we have to get a higher value within each item.

By repetition of this procedure through the necessary period, it is possible to get a time series $I_{\mathrm{i}}$ of irrigation water.

\section{ESTIMATION OF WATER REQUIREMENT}

\section{Water balance model and equation}

It is possible to make a water balance model as Fig. 5 in paddy field. The water balance equation is as follows:

$$
S_{i}=S_{i-1}+R e_{i}+I_{i}-E T_{i}-P_{i}
$$

Where $S_{\mathrm{i}}$ is ponding depth on the $\mathrm{i}^{\text {th }}$ day, $S_{\mathrm{i}-1}$ is ponding depth on the (i-1) $)^{\text {th }}$ day, $R_{\mathrm{i}}$ is rainfall on the $\mathrm{i}^{\text {th }}$ day, $I_{\mathrm{i}}$ is amount of irrigated water on the $\mathrm{i}^{\text {th }}$ day, $E T_{\mathrm{i}}$ is evapotranspiration on the $\mathrm{i}^{\text {th }}$ day and $P_{\mathrm{i}}$ is percoration on the $\mathrm{i}^{\text {th }}$ day.

In Fig. $5, S_{\text {op }}$ is operated ponding depth and $S_{\max }$ is height of levee.

\section{Estimation of the factors concerning the water balance}

Estimation of consumptive water use

We can rewrite the water balance equation as follows:

$$
I_{i} \leq S_{o p}-S_{i-1}-R e_{i}+E T_{i}+P_{i}
$$

It is clear from equation (10) that items, which are percolation $\left(P_{1}\right)$, evapotranspiration $\left(E T_{\mathrm{i}}\right)$ and operated ponding depth $\left(S_{\mathrm{op}}\right)$, are necessary to estimate the amount of irrigation water requirement.

Consumptive water use in the paddy field is the sum of evapotranspiration and perco- 
lation, and it is called "Gensuishin" in Japan.

\section{Evapotranspiration}

As already mentioned, potential evaporation calculated by Penman's method multiplied by crop coefficient gives evapotranspiration. Therefore, it is possible to calculate using meteorological data.

\section{Percolation}

There is the possibility that percolation in a land consolidation area is different from in a nonconsolidation area. This is reason in a land consolidation area irrigation canals and drainage ditches are constructed, but in a nonconsolidation area the irrigation method is plot to plot irrigation. Therefore we have to measure percolation in the field. The result shall be reported in the next report.

\section{Operated ponding depth}

As mentioned above, it is possible to measure the ponding depth in a paddy field. By measuring water level while rice is growing it is possible to grasp operated ponding depth for each period of growth. In the case of irrigation in a paddy field, as it is assumed that we recover to operated ponding depth, this value is very important for deciding irrigation water.

\section{Estimation method of irrigation water \\ Simulation method}

When irrigation water requirement is calculated by equation (10), if operated ponding depth and effective rainfall are not clarified, irrigation water requirement cannot be determined. There are two irrigation methods the same as in the case of upland field. We have to decide the irrigation method based on the results of ponding depth investigation. I will explain the estimation method of amount of irrigation water requirement on the assumption that operated ponding depth is set through the growing period.

\section{Effective rainfall $\left(R e_{i}\right)$}

We make $80 \%$ of daily rainfall over $5 \mathrm{~mm}$ first of all to be the effective rainfall.

Ponding depth $\left(S_{\mathrm{i}}\right)$ is forbidden to exceed height of levee $\left(S_{\max }\right)$. Then ponding depth $\left(S_{\mathrm{i}}\right)$ will be as follows:

$$
S_{i} \leqq S_{\max }
$$

Therefore, from equation (9) maximum value of effective rainfall is as follows:

$$
R e_{\max }=S_{\max }-S_{i-1}+E T_{i}+P_{i}
$$

Accordingly, effecitive rainfall is as follows:

$$
R e_{i}=\min \left(R_{i} * 0.8, R e_{\text {max }}\right)
$$


Where $\min \left(x_{1}, x_{2}\right)$ means that we have to get a lower value within each item.

Irrigation water $\left(I_{i}\right)$

Irrigation water means the amount of water necessary to recover the ponding depth to operated ponding depth $\left(S_{\mathrm{op}}\right)$.

$$
I_{i}=\max \left(S_{o p}-S_{i-1}-R e_{i}+E T_{i}+P_{i}, 0\right)
$$

Where $\max \left(x_{1}, x_{2}\right)$ means that we have to get a higher value within each item.

Here, I used the max function, because we will not change a water level and not irrigate when ponding depth exceeds the operated ponding depth by the rainfall.

By repetition of this procedure through the necessary period, it is possible to get a time series $I_{\mathrm{i}}$ of irrigation water.

\section{CONCLUSION}

The model which calculated the time series of upland field irrigation water and paddy field irrigation water in the Thailand gravity irrigation district was developed.

The factor for the irrigation water calculation also clarified in the upland field.

The material could not insufficiently clarify all factors on the paddy field.

Therefore, it is necessary to clarify percolation and operated ponding depth in order to calculate paddy field irrigation water in the model actually.

The factor of these paddy fields should be clarified by the observation.

\section{REFERENCES}

Akira Ishikawa 1992 The Novel Development of Field Irrigation. In "Consumptive Water Use and Evapotranspiration", by Takeshi Miura, Agricultural Upland Development Association, Japan, pp. 136-160

Royal Irrigation Department 1990 Crop Coefficient and Pan Coefficient (Thailand)

Toshisuke Maruyama 1995 New edition irrigation and drainage, Yokendo 